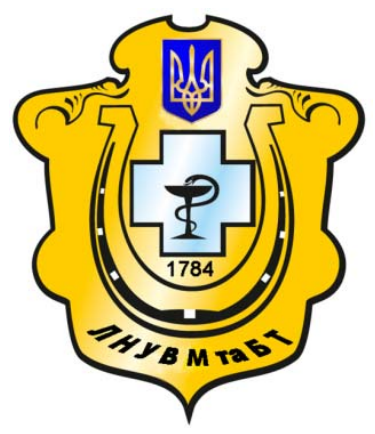

Науковий вісник Львівського національного університету ветеринарної медицини та біотехнологій імені С.3. Гжицького

Scientific Messenger of Lviv National University of Veterinary Medicine and Biotechnologies named after S.Z. Gzhytskyj

doi:10.15421/nvlvet7103

ISSN 2413-5550 print

ISSN 2518-1327 online

$\underline{\text { http://nvlvet.com.ua/ }}$

\title{
Показники азотового обміну курчат-бройлерів кросу Росс-308 за сумісної дії охратоксину А та дезоксиніваленолу
}

\author{
В.Б. Духницький, Ю.В. Бойко, Г.В. Бойко, Н.І. Бойко \\ boikoyv@gmail.com
}

\begin{abstract}
Національний університет біоресурсів і природокористування Украӥни, вул. Героїв Оборони, 11, м. Київ, 03041, Украӥна
\end{abstract}

\begin{abstract}
Мікотоксикози сільськогосподарських тварин завдають загалом величезних збитків у світовому масштабі, а тому розробка нових методів їх лікування та запобігання надходженню мікотоксинів в організм тварин залишається пріоритетним напрямком у ветеринарній токсикології.

На сьогодні є розуміння того, що переважну більшість випадків мікотоксикозів тварин складають саме змішані мікотоксикози, які є результатом токсичної дії складних комплексів різних мікотоксинів, щуо ускладнює їх діагностику, профілактику та лікування.

Більшість мікотоксикозів тварин є хронічними захворюваннями, при яких порушується обмін речовин, а найбільш вразливими є лімфоїдні органи, печінка, залози внутрімньої секреції та центральна нервова система. Тому лікування тварин повинне бути комплексним - антидотним, патогенетичним та симптоматичним, а пошук нових засобів боротьби з мікотоксикозами тварин є актуальним науковим напрямком у сучасній ветеринарній медицині.

У статті наведені експериментальні дані щодо комбінованої дї охратоксину А та дезоксиніваленолу на показники азотового обміну у курчат-бройлерів. Стан азотового обміну в організмі курчат-бройлерів вивчали за вмістом загального білку, альбуміну, сечовини та креатиніну. Встановлено, що комбінована дія охратоксину А та дезоксиніваленолу на курчат-бройлерів проявляється диспротеїнемією, що є результатом порушення білоксинезувальної функиії печінки $і$ всмоктування продуктів розщеплення білка з тонкої кишки, внаслідок ураження слизової оболонки токсинами.

Зростання рівня сечовини і креатиніну у плазмі крові курчат-бройлерів за комбінованої дї охратоксину А та дезоксиніваленолу є результатом порушенням видільної функції нирок внаслідок впливу на них токсинів.

Ключові слова: курчата-бройлери, азотовий обмін, охратоксини А, дезоксиніваленол, мікотоксини, мікотоксикози.
\end{abstract}

\section{Показатели азотного обмена цыплят-бройлеров кросса Росс-308 при сов- местной действии охратоксина А и дезоксиниваленола.}

\author{
В.Б. Духницький, Ю.В. Бойко, Г.В. Бойко, Н.І. Бойко \\ boikoyv@gmail.com
}

Национальный уныверситет биоресурсов и природопользования Украины, ул. Героев Обороны, 11, Киев, 03041, Украина

\begin{abstract}
Микотоксикозы сельскохозяйственных животных в целом наносят огромный ущерб в мировом масштабе, а поэтому разработка новых методов их лечения и предотвращения поступления микотоксинов в организм животных остается приоритетным направлением в ветеринарной токсикологии.

В настоящее время есть понимание того, что подавляющее больиинство случаев микотоксикозов животных составляют именно смешанные микотоксикозы, которые являются результатом токсического действия сложных комплексов различных микотоксинов, что усложняет их диагностику, профилактику и лечение.
\end{abstract}

\section{Citation:}

Duhnytskyy, V.B., Boiko, Y.V., Boiko, G.V., Boiko, N.I. (2016). Parameters of nitrogenous metabolism in broiler chickens by the joint action of ochratoxin A and deoxynivalenol. Scientific Messenger LNUVMBT named after S.Z. Gzhytskyj, 18, 3(71), 11-14. 
Большинство микотоксикозов животных являются хроническими заболеваниями, при которых нарушается обмен вещееств, а наиболее уязвимыми являются лимфоидные органы, печень, железы внутренней секреции, иентральная нервная система. Поэтому лечение животных должно быть комплексным - антидотним, патогенетическим и симптоматическим, а поиск новых средств борьбы с микотоксикозами животных - актуальное научное направление в современной ветеринарной медицине.

В статье приведены экспериментальные данные по комбинированному действию охратоксина А и дезоксиниваленола на показатели азотного обмена у изыплят-бройлеров. Состояние азотного обмена в организме изыплят-бройлеров изучали по содержанию общего белка, альбумина, мочевины и креатинина. Установлено, что комбинированное действие охратоксина А и дезоксиниваленола на иыллят-бройлеров проявляется диспротеинемией, что является результатом нарушения белоксинтезирующей функиии печени и всасывания продуктов расщепления белка с тонкой кишки, в результате поражения слизистой оболочки токсинами.

Увеличение уровня мочевины и креатинина в плазме крови изыплят-бройлеров при комбинированном действии охратоксина $А$ и дезоксиниваленола является результатом нарушения выделительной функции почек вследствие воздействия на них токсинов.

Ключевые слова: иыллята-бройлеры, азотный обмен, охратоксин А, дезоксиниваленол, микотоксины, микотоксикозыл.

\title{
Parameters of nitrogenous metabolism in broiler chickens by the joint action of ochratoxin A and deoxynivalenol
}

\author{
V.B. Duhnytskyy, Y.V. Boiko, G.V. Boiko, N.I. Boiko \\ boikoyv@gmail.com \\ National University of Life and Enviromental Sciences of Ukrain, \\ Heroyiv Oborony Str., 11, Kyiv, 03041, Ukraine
}

\begin{abstract}
Mycotoxicoses of farm animals cause the huge losses on a global scale, therefore the development of new methods for their treatment and prevention mycotoxins entry to organism of animals is still priority in veterinary toxicology.

Today the understanding that the vast majority of animals mycotoxicoses cases is the mixed mycotoxicoses, that are resulting toxic effects of complex set of different mycotoxins, which complicates their diagnostics and prevention and treatment.

Most of animals mycotoxicoses is a chronic disease at which disturbed metabolism, and the most vulnerable are lymphoid organs, liver, ductless glands and central nervous system. Therefore, treatment of animals should be complex - antidote, pathogenetic and symptomatic, and the search for new tools in the fight against mycotoxicosis in animals is a topical research direction in modern veterinary medicine.

The article presents the experimental data about joint action of ochratoxin A and deoxynivalenol on nitrogenous metabolism parameters of broiler chickens. Conditions of nitrogenous metabolism in the organism of broiler chickens were studied by content of total protein, albumin, urea and creatinine. Established that the joint action of ochratoxin A and deoxynivalenol to the broiler chickens manifested dysproteinemia, that is the result of liver protein synthesis function disorder and absorption of protein cleavage products from the small intestine, owing to mucous membrane lesions through toxins. Increase of urea and creatinine in the blood plasma of broiler chickens by combined effect of ochratoxin A and deoxynivalenol is a result of disorder of renal excretory function due to exposure to toxins.
\end{abstract}

Key words: broiler chickens, nitrogenous metabolism, ochratoxin A, deoxynivalenol, mycotoxins, mycotoxicoses

\section{Вступ}

Об'єднаний комітет експертів ФАО/ВООЗ з харчових добавок (JECFA) у своїх доповідях «Оцінка деяких харчових добавок та контамінантів» розглядає мікотоксини як один із факторів, здатних негативно впливати на якість продукції та на стан здоров'я населення загалом. Згідно з доповіддю Комітету експертів, темою якої є оцінка мікотоксинів у кормах, мікотоксини становлять реальну небезпеку здоров'ю людини у світовому масштабі (Marasas, 2000).

На сьогодні доведено, що безпечних рівнів мікотоксинів у кормах та харчовій сировині не існує. Навіть у невеликих кількостях, але в результаті багаторазового надходження вони проявляють різноманітну дію, в т.ч. канцерогенну, а багато із них володіють також мутагенними, тератогенними та імуносупресивними властивостями, а згодом здатні накопичуватися в організмі (Duhnic'kij et al., 2011).

Пошук та апробація нових ефективних засобів лікування та профілактики комбінованих (змішаних) мікотоксикозів та лікування тварин за їх виникнення, потребує використання стабільно відтворюваних експериментальних моделей змішаних мікотоксикозів лабораторних тварин та птиці.

Мета дослідження - вивчити комбіновану дію охратоксину А та дезоксиніваленолу у складі кормів на організм курчат-бройлерів за показниками азотового обміну.

\section{Матеріал і методи досліджень}

Для дослідження було відібрано відібрано 30 курчат-бройлерів кросу Ross 308 добового віку, яких за принципом аналогів розподілили на 2 групи - контрольну і дослідну по 15 курчат у кожній. Протягом 5и діб був проведений вирівнювальний період, під час якого курчата адаптувались до умов утримання та годівлі. 3 шостої доби курчатам-бройлерам контрольної групи згодовували корми базового раціону, які були вільні від мікотоксинів. Курчатам-бройлерам дослідної групи згодовували суміш комбікорму та дерті вівса, пшениці, кукурудзи, що містила охратоксин А та дезоксиніваленол. Матеріалом для дослі- 
джень була кров, відібрана від курчат-бройлерів на 14-у, 22-у, 35-у та 42-у добу життя. У крові визначали вміст загального білку, альбуміну, сечовини i креатиніну (Kamyshnikov, 2000).

\section{Результати та їх обговорення}

Для вивчення механізму сумісної дії охратоксину та дезоксиніваленолу на організм курчат-бройлерів важливе значення має вивчення стану обмінних процесів. Отримані результати біохімічних досліджень крові курчат-бройлерів за сумісної дії охратоксину А та дезоксиніваленолу, свідчать про порушення азотового обміну. (табл. 1).

Таблиия 1

Показники азотового обміну курчат-бройлерів за сумісної дії охратоксину А та дезоксиніваленолу $(\mathbf{M} \pm \mathbf{m}, \mathbf{n}=\mathbf{1 5})$

\begin{tabular}{|c|c|c|c|c|c|c|}
\hline \multirow{2}{*}{$\begin{array}{c}\text { № } \\
\text { П/ா } \\
\end{array}$} & \multirow{2}{*}{ Показник } & \multirow{2}{*}{ Група птиці } & \multicolumn{4}{|c|}{ Вік курчат-бройлерів, діб } \\
\hline & & & 14 & 22 & 35 & 42 \\
\hline \multirow{2}{*}{1.} & \multirow{2}{*}{$\begin{array}{c}\text { Білок загальний, } \\
\text { г/л }\end{array}$} & контрольна & $33,85 \pm 0,71$ & $24,14 \pm 1,03$ & $21,39 \pm 1,11$ & $28,63 \pm 0,35$ \\
\hline & & дослідна & $36,68 \pm 3,34$ & $26,19 \pm 1,05$ & $24,35 \pm 0,54^{*}$ & $34,22 \pm 1,60^{*}$ \\
\hline \multirow{2}{*}{2.} & \multirow{2}{*}{ Альбумін, г/л } & контрольна & $29,64 \pm 0,76$ & $16,32 \pm 0,44$ & $18,76 \pm 0,47^{*}$ & $30,68 \pm 0,56^{*}$ \\
\hline & & дослідна & $24,80 \pm 1,81^{*}$ & $15,76 \pm 0,48$ & $14,09 \pm 1,16$ & $26,74 \pm 0,63$ \\
\hline \multirow{2}{*}{3.} & \multirow{2}{*}{ Сечовина, ммоль/л } & контрольна & $0,32 \pm 0,01$ & $0,60 \pm 0,01$ & $0,51 \pm 0,01$ & $0,58 \pm 0,05$ \\
\hline & & дослідна & $1,89 \pm 0,31^{*}$ & $0,75 \pm 0,06^{*}$ & $1,43 \pm 0,28^{*}$ & $1,40 \pm 0,23 *$ \\
\hline \multirow{2}{*}{4.} & \multirow{2}{*}{$\begin{array}{l}\text { Креатинін, } \\
\text { мкмоль/л }\end{array}$} & контрольна & $67,99 \pm 0,64$ & $94,32 \pm 4,14$ & $53,74 \pm 1,23$ & $202,48 \pm 2,77$ \\
\hline & & дослідна & $95,50 \pm 5,08^{*}$ & $100,64 \pm 0,65$ & $59,81 \pm 2,37^{*}$ & $236,90 \pm 10,33 *$ \\
\hline
\end{tabular}

Примітка: *(P $\leq 0,05)$ порівняно з контролем.

Результати наших досліджень показали, що вміст загального білка та білкових фракцій плазми крові курчат-бройлерів змінюється протягом всього експерименту в птиці контрольної та дослідної груп.

Так, вміст загального білка (табл. 1) у крові курчат-бройлерів контрольної групи на 22 добу досліду був нижчим, ніж на 14 добу на 28,7\% (P $\leq 0,05)$, на 35 і 42 добу відповідно на 36,8\% і 15,4\%. Такі зміни вмісту загального білка в крові можливо пов'язані з фізіологічними (віковими) особливостями розвитку курчат-бройлерів кросу РОСС-308. У крові курчатбройлерів, яким згодовували корм, контамінований мікотоксинами, зміни вмісту загального білка плазми крові були схожі. В плазмі крові курчат дослідної групи вміст загального білка на 22 добу досліду був меншим ніж на 14 добу на 28,6\%, а на 35 і 42 доби відповідно на 33,6\% і 6,7\% (табл. 1).

Аналогічні зміни спостерігали при дослідженні вмісту альбуміну (табл. 1). У курчат контрольної групи показник на 22 добу був нижчим у порівнянні 3 початковим показником на 44,9\%, на 35 добу на $52,5 \%$, а на $42-$ - - на 9,78\%.

Зменшення вмісту альбуміну в плазмі крові протягом перших трьох періодів спостерігали в курчат дослідної групи на 22 добу - на $36,4 \%$, на 35 - на 24,4\%. Проте, на 42 добу вміст альбуміну в плазмі крові курчат дослідної групи дещо підвищився і був в межах початкового періоду (табл. 1).

Аналізуючи показники вмісту загального білка i білкових фракцій у плазмі крові курчат-бройлерів за комбінованої дії охратоксину А та дезокисніваленолу необхідно відмітити, що вірогідна різниця між птицею контрольної і дослідної груп спостерігалась 335 доби досліду.

Таким чином, нами було встановлено, що у плазмі крові курчат-бройлерів кросу РОСС-308 на 22 добу дослідження вміст загального білку і альбумінів був майже в два рази нижчим, ніж на 14 добу. Зниження вмісту загального білку та альбумінів у плазмі крові очевидно є фізіологічним, оскільки показники як у птиці контрольної так і дослідної груп (ОТА+ДОН) мали однакову закономірність.

Проте, вже на 35 і 42 доби досліду було встановлено поступове збільшення вмісту загального білка в плазмі крові птиці обох груп. В ці періоди досліджень вміст альбуміну в плазмі крові дослідної групи був вірогідно меншим на 24,9\% і 12,8\%, ніж у контролі (табл. 1).

Зменшення вмісту альбумінів за одночасного зростання рівня загального білку оцінюють як диспротеїнемію, що настає внаслідок порушення білоксинезувальної функції печінки. з одного боку, а з іншого - як результат порушення всмоктування продуктів розщеплення білка 3 тонкої кишки, що настає внаслідок ураження слизової оболонки токсинами.

Для поглибленого вивчення обміну білків в організмі курчат-бройлерів необхідні дані щодо динаміки вмісту в крові небілкових азотистих компонентів плазми крові. Результати досліджень показали, що у крові курчат-бройлерів за сумісної дії охратоксину та дезоксиніваленолу зростав рівень сечовини і креатиніну.

У плазмі крові курчат-бройлерів контрольної групи вміст сечовини протягом досліду був в межах $0,32 \pm 0,01-0,60 \pm 0,01$ ммоль/л, що відповідає фізіологічному значенню для курей-бройлерів. Концентрація сечовини у плазмі крові курчат дослідної групи була значно більшою, ніж в контролі. Вже на 14-у добу досліду вміст сечовини у плазмі крові курчатбройлерів дослідної групи був вірогідно вищим у 5,9 разу $(\mathrm{P} \leq 0,05)$. У наступні періоди досліджень $(22,35$, 42 доби) вміст сечовини знижувався проти показника 14 доби майже в два рази, але був вірогідно вищим проти показника у птиці контрольної групи в 2,8 і 2,4 раза.

Вивчення стану обміну обміну білків у курчатбройлерів за змішаного мікотоксикозу передбачало дослідження рівня креатиніну у плазмі крові. В плазмі крові курчат-бройлерів контрольної групи цей показник протягом перших трьох періодів досліджень (14, 
22, 35 доби) знаходився в межах 53 - 94 мкмоль/л, що відповідає нормативним показникам. В ці періоди досліджень у плазмі крові курчат дослідної групи рівень креатиніну не відрізнявся від контролю, але спостерігалось незначна тенденція до його зростання. На 42 добу дослідження виявили різке збільшення концентрації креатиніну в плазмі крові курчат обох груп. Порівняно 3 вихідними показниками рівень креатиніну в плазмі крові птиці обох груп був більшим майже у 3,0 рази. Проте, у курчат дослідної групи рівень креатиніну в цей період вірогідно перевищував контроль на $11 \%(\mathrm{P} \leq 0,05)$.

Отже, за комбінованої дії охратоксину А та дезоксиніваленолу у плазмі крові курчат-бройлерів різко зростає рівень небілкових азотистих компонентів (сечовини і креатиніну), що можна пояснити порушенням видільної функції нирок внаслідок впливу на них токсинів.

\section{Висновки}

Стан азотового обміну в організмі курчатбройлерів за експериментального отруєння охратоксином та дезоксиніваленолом характеризувався диспротеїнемією, яка проявлялася зростанням вмісту загального білка за зниження вмісту альбумінів у крові, а також підвищенням рівня небілкових азотистих компонентів (сечовини і креатиніну).

Перспективи подальших досліджень. Для більш повного дослідження впливу сумісної дії охратоксину та дезоксиніваленолу на курчат-бройлерів за хронічного токсикозу, доцільно вивчити показники вуглеводного та мінерального обміну.

\section{Бібліографічні посилання}

Evaluation of certain mycotoxins in food: fifty-sixth report of the Joint FAO/WHO Expert Committee on Food Additives (WHO technical report series; 908). Geneva, 2002, 62.

Marasas, W.F. (2000). Fusarium mycotoxins in the third millennium: Pap. 6 th European Fusarium Seminar and Third COST 835 Workshop of Agriculturally Important Toxigenie Fungi. Berlin. 11-16 Sept. 2000. Mitt. Biol. Bundesanst. Land-und Forstwirt. 377, 42.

Duhnic'kij, V.B., Hmel'nic'kij, G.O., Bojko, G.V., Ishchenko, V.D. (2011). Veterinarna mikotoksikologiya: navch. posib. K.: Agrarna osvita (in Ukrainian).

Kamyshnikov, V.S. (2000). Spravochnik po kliniko biohimicheskoj laboratornoj diagnostike: V2. Minsk.: Belarus' (in Ukrainian).

Стаття надійшла до редакиії 30.09.2016 